\title{
Communication Barrier Encountered By Employees Working In Hotel Industry
}

\author{
X. DISILVA \\ School of Hotel \& Catering Management \\ Vels University, P. V. Vaithiyalingam Salai \\ Velan Nagar, Chennai, India.
}

A. ARUN

School of Hotel \& Catering Management

Vels University, P. V. Vaithiyalingam Salai

Velan Nagar, Chennai, India.

\begin{abstract}
Objective: Communication in English is an important antecedent for a noteworthy work performance in hospitality industry. English has been considered the universal language, an employee into hospitality sector is expected to be more communicative in English language to service guest with no geographic bounds and coordinate immigrant employees from any part of the world. The study discusses the barriers and the importance of English communication skill among the employees into food and beverage outlets in hotel Industry. Method: A systematically structured questionnaire is used as a survey tool for the study to bring out the barriers of communication in English and effective measure to overcome the barriers. The advantages of an effective communication in enhancing the guest service and to maintain a cultured work environment is discussed. SPSS (21.0) statistics analysis software is used to analyze and interpret the data. Finding: An employee's personal attributes education level psychological factors acts as the barriers for communication in English these factors are interrelated. Conclusion: The study conclude that regular training and practice sessions are required even more effectively to the employees to develop their communication and grow higher in their carrier.
\end{abstract}

Key Words: Communication, , Employees, Hospitality , Service,

\section{INTRODUCTION}

Hospitality is a one among the profitable sector enduring its development by servicing guest, the business traveler or a tourist for recreation. The consumers or the guest for a hotel may not restrict to any geographical boundaries. Communication plays an imperative role in servicing the guest; an employee with an eminent communication skill preeminently services his guest. In the hotel sector English - is widely used for communication, English is a global language which has been used as a first language by 350 million native speakers, as a second language and foreign language by 1900 million speakers. ${ }^{1}$ Being communicative in English the traveler can travel to any part of the world.

Hotel industry serves the guest more manually the employees should be communicatively presentable to serve his guest. Employees at departments like Front Office, Food and Beverage Service, Accommodation Operation, sales and marketing are urged to provide information to the guest. The employee must be able to understand the guest requirement and provide correct information. Scuffled and vacillated information from the employee may create negative impression about the concern results descend in business. 
Being an employee at hotel industry the communication may stats up with an enquiry with a visitor where he is from, explaining the guest about the facilities, climate or tourist amenities, coordinating or exchanging messages officially within or between the departments and waiving a good bye chat with the guest or co-worker. English used at hotel industry is wellmannered and ceremonial. An employee at all levels from lower to top levels of management is required to be well versed in hotel English which requires no literature, repeated phrases are used as the situation faced at industry are more common and regular ${ }^{2}$.

An employee verbally communicative in English is more confident and self esteemed, can treat a guest more prominent. He is self sufficient; perceive a good command over his subordinates and the co-workers that boost up a better work environment.

Communication could not be categorized under a congenital skill an employee is made communicative through periodic trainings and personal development programs.

The objective of the study deals with the finding of communication barriers at the Food and Beverage Service department in star hotels at Chennai and remedies to overcome the fact. Communication in English language of the employees at the lower level of management is assessed by the employees at top and middle levels of management. The study illustrates the barriers and break through measures to enhance the communication of the employees.

\section{REVIEW OF LITERATURE}

The hotel industry is chief outlet of hospitality industry that serves people from all sectors. A guest expects an outstanding service during their stay in hotel. It would be complicated to afford a guest an extraordinary service without communicating with them about their prospect. Communication is a form of interaction between one or more than one person which may constitute a verbal or non verbal conversations, provided there exist exchange of ideas or feedbacks.

Hospitality employees have no bounds to work; English language plays a prominent role to communicate with co- immigrant employees to enhance job performance. (Juan M. Madera (2012) $^{3}$. At workplace like hotel industry communication play an immersive role to make the environment with a peace and pleasant ambience. To hold this ambience the communication is more required to achieve a high productivity at hotel industry. (Ms. Mubeena Iqbal 2014) ${ }^{4}$

The employees at hotel industry faces many barriers to overcome for an effective communication in English these barriers can be segmented into four categories namely the process barriers, physical barriers, psychological barriers and semantic. Process barriers and the physical barriers are more oriented towards the external factors like distraction due to telephone calls, attending more guests at a time, mismatch between the encoder, receiver and medium. (Fred C. Lunenburg (2010) $)^{5}$

The barriers like semantic barrier and the psychological barrier are more closely linked with the employees that affect their communication in English among the employees into food and beverage service department. Semantic barrier is due to a wrong interpretation of the word, with a connotative and denotative meaning. (Aradhna Malik (2015) ${ }^{6}$ Semantic barrier arise while there exist indifference in language, culture and education levels. The hotel employees' services guest from various geographical and cultural diversities with different accents or slang creates a communication issue. (Sneha Mishra (2017) ${ }^{7}$ 
Psychological barriers can be just as unfathomable as more understandable barriers, such as language differences, unless you become aware of them. This arises when the employee is not psychologically confident in his language or his standard operating procedures in the industry. Major causes for the obstacles are attitude, lack of attention, emotion, impulsive evaluation by the employees. (Karen S. Johnson) ${ }^{8}$

The barriers faced by employees while communicating in English can be overcome by training and development measures. An employee good in basic standard operating procedures at department can confidently face a situation and handle smoothly. Usage of simple language avoiding idioms can make the communication more effective. (By Kate Berardo (2007) Conduction of frequent training programs constituting updated trends and techniques, workshops, seminar and lecture activities improves the communication of the employees internally the department, royal and loyal service to the guest. (Cristian Grossmann (2015) ${ }^{10}$ Effective communication with the guest always builds up a friendliness and professionalism among the guest and employees. ${ }^{11}$ (Nektaria Tziora et.al (2009)

\section{MATERIALS AND METHOD}

The study principally concentrates to assess the barriers of communication of the employees engaged with the Food and Beverage Service Department in hotel at Chennai. Data were collected with a questionnaire sectioned with the demographic statuses, barriers of communication and effective measure to improve the communication among employees. The employees at top level and middle level management at Food and Beverage Service Management were targeted as the respondents as they were the exact person to evaluate the communication skill of their department employees.

The questionnaire was distributed among 150 respondents employed at Food and Beverage Outlets at 21 selected star categorized hotels covering all areas of Chennai. 102 responses were considered and rest rejected for exactness.

Data collected was statistically scrutinized with SPSS (Version 21.0) software. Research questions were analyzed in general and interpreted

\section{RESULT AND DISCUSSION}

The data collected for the top level and the middle level employees of the food and beverage service department of selected hotels in Chennai were checked for the reliability using SPSS(21.0) software where it shows that the data are reliable Cronbach's Alpha value (0.753). The employees were expected to be more communicative in English(69.3\%) than the other languages like French, Hindi or the regions local language. Communication in English is considered an important attribute for the employee to offer a best service to the guest and maintain a peaceful work ambience.

$\mathbf{H}_{\mathbf{1}}$ Poor communication skill has a significant effect on employee confidence level

$\mathbf{H}_{\mathbf{0}}$ Poor communication has no significant effect on employee confidence level 


(Table1)Test Statistics
\begin{tabular}{|l|l|}
\hline & confidence \\
\hline Chi-Square & $65.922^{\mathrm{a}}$ \\
Df & 1 \\
Asymp. Sig. & .000 \\
\hline
\end{tabular}
a. 0 cells $(0.0 \%)$ have
expected frequencies
less than 5 . The
minimum expected cell
frequency is 51.0 .

From Table 1 it is recognized that the value of chi- square is high (65.922) with a degree of freedom 1, and more significant at the level of (0.00). It Illustrates that the employees at food and beverage production department feels more confident when there are highly skilled in English communication the employees with poor communication feels himself inferior, reserved and panic in handling the situations while serving the guest or co-ordinating among the employees within or between the department.

$\mathbf{H}_{1}$ The development programs adopted by the hoteliers improves the employees communication skill

$\mathbf{H}_{0}$ Development programs adopted by hoteliers does not develops employees communication skill

The analysed data results that there is a positive correlation with a person's correlation value (0. 836) and the correlation is highly significant at the 0.01 level. This shows that programs adopted for the development of communication skills of employees in food and beverage department have a positive effect and development in employees to develop themselves in English communication hence the alternative hypothesis is accepted.

$\mathbf{H}_{1}$ Level of education has an impact on employee's communication in English

$\mathbf{H}_{\mathbf{0}}$ Level of education has no impact on the employee's communication in English

The statistical analysis using $\mathrm{T}$ - test interprets that there the educational levels of the employees working in the department have an impact on their communication skills in English. The test show that the $t$-value is 3.244332 . The $P$-Value is 0.001597 . The result is significant at $\mathrm{p}<0.05$. Hence the alternative hypothesis is accepted as the level of education of the employees is having a great impact on the communication skill of the employees working in the food and beverage department.

The employees of the department rank the lack of training and development programs (65.2\%) stand first among the barriers of communication. To overcome the barriers of communication they also appeal for appropriate training programs (89.1\%). Thus the employees of Food and Beverage Service department at hotel industry feels that conducting regular training and development program for the employees may develop their communication skill in English.

\section{CONCLUSION}

Communication in English is always considered an attribute in employee selection at hospitality industry. They are close knitted with the guest and repute the concern in service. The study determines the barriers for communication and recommends conducting periodic training and development program as the measure to develop the employees psychologically to overcome the communication barriers. 


\section{References}

Zuliati Rohmah. English as a global language: Its historical past and its future. Jurnal Bahasa \& Seni, 33(1), 106117.

Yuliyageikhman. Why Learning English for the Hotel Industry Is a Great Idea, and How to Start. [Cited on $13^{\text {th }}$ March 2017] Available at: http://www.fluentu.com/english/blog/english-for-hotel-industry/

Juan M. Madera, Mary Dawson, Jack A. Neal, Kristin Busch. Breaking A Communication Barrier. The Effect of Visual Aids in Food Preparation on Job Attitudes and Performance. Journal of Hospitality \& Tourism Research, vol. 37, 2: pp. 262-280. , 2012.

Ms. Mubeena Iqbal. A Study of the Significance of Business Communication in the Hotel Industry of Dubai Available at: http://jaipuria.edu.in/pgdm/wp-content/uploads/2014/03/A-Study-of-the-Significance-ofBusiness-Communication-in-the-Hotel-Industry-of-Dubai.pdf

Fred C. Lunenburg. Communication: The Process, Barriers, and Improving Effectiveness. [Cited on 25th March 2017] Available at

http://www.nationalforum.com/Electronic\%20Journal\%20Volumes/Lunenburg,\%20Fred\%20C,\%20Communica tion\%20Schooling\%20V1\%20N1\%202010.pdf

Aradhna Malik. Semantic Barriers to Communication. International Business Communication. [cited on $4^{\text {th }}$ April 2017] Available at: http://nptel.ac.in/courses/110105051/m13l13.pdf

Sneha Mishra. Semantic Barriers of Communication. Businesstopia [ Cited on 4th April 2017] Available at: https://www.businesstopia.net/communication/semantic-barriers-communication

Karen S. Johnson. Psychological Barriers in Communication. Chron (2017) [Cited on 28 ${ }^{\text {th }}$ March 2017] Available at: http://work.chron.com/psychological-barriers-communication-8309.html

By Kate Berardo. 10 Strategies for Overcoming Language Barriers (2007) Culturosity.com. [Cited on $5^{\text {th }}$ April 2017] Available at:

http://www.culturosity.com/pdfs/10\%20Strategies\%20for\%200vercoming\%20Language\%20Barriers.pdf

Cristian Grossmann. Best Practice, Business Cases, Trends [ Updated on 18 ${ }^{\text {th }}$ May 2015: Cited on $6^{\text {th }}$ April 2017] Available at :https://beekeeper.io/5-ways-to-improve-internal-communications-in-your-hotel/

Nektaria Tziora. Nikolaos Giovanis. \& Charalabos Papacharalabous. The role of foreign languages in hospitality management. (2009) [Cited on $4^{\text {th }}$ April 2017] Available at:

http://ejournals.epublishing.ekt.gr/index.php/latic/article/viewFile/10353/10456.pdf 